\title{
Linking fruit traits to variation in predispersal vertebrate seed predation, insect seed predation, and pathogen attack
}

\author{
Noelle G. Beckman ${ }^{1,2,3}$ and Helene C. Muller-Landau ${ }^{1}$ \\ ${ }^{1}$ Smithsonian Tropical Research Institute, Unit 9100 Box 0948, DPO AA 34002 \\ ${ }^{2}$ Ecology, Evolution, and Behavior, University of Minnesota-Twin Cities, Saint Paul, Minnesota 55108 USA
}

\begin{abstract}
The importance of vertebrates, invertebrates, and pathogens for plant communities has long been recognized, but their absolute and relative importance in early recruitment of multiple coexisting tropical plant species has not been quantified. Further, little is known about the relationship of fruit traits to seed mortality due to natural enemies in tropical plants. To investigate the influences of vertebrates, invertebrates, and pathogens on reproduction of seven canopy plant species varying in fruit traits, we quantified reductions in fruit development and seed germination due to vertebrates, invertebrates, and fungal pathogens through experimental removal of these enemies using canopy exclosures, insecticide, and fungicide, respectively. We also measured morphological fruit traits hypothesized to mediate interactions of plants with natural enemies of seeds. Vertebrates, invertebrates, and fungi differentially affected predispersal seed mortality depending on the plant species. Fruit morphology explained some variation among species; species with larger fruit and less physical protection surrounding seeds exhibited greater negative effects of fungi on fruit development and germination and experienced reduced seed survival integrated over fruit development and germination in response to vertebrates. Within species, variation in seed size also contributed to variation in natural enemy effects on seed viability. Further, seedling growth was higher for seeds that developed in vertebrate exclosures for Anacardium excelsum and under the fungicide treatment for Castilla elastica, suggesting that predispersal effects of natural enemies may carry through to the seedling stage. This is the first experimental test of the relative effects of vertebrates, invertebrates, and pathogens on seed survival in the canopy. This study motivates further investigation to determine the generality of our results for plant communities. If there is strong variation in natural enemy attack among species related to differences in fruit morphology, then quantification of fruit traits will aid in predicting the outcomes of interactions between plants and their natural enemies. This is particularly important in tropical forests, where high species diversity makes it logistically impossible to study every plant life history stage of every species.
\end{abstract}

Key words: fruit development; fruit morphology; germination; Janzen-Connell effects; natural enemies; Panama; plant traits; predispersal seed mortality; seed survival.

\section{INTRODUCTION}

Vertebrates, invertebrates, and microbes all influence plant survival, population dynamics, and species distributions (Coley and Barone 1996, Crawley 1997b, Gilbert 2002, Maron and Crone 2006). Some of these influences are positive, as vertebrates may be seed dispersers or pollinators, invertebrates may be pollinators or other mutualist symbionts such as in ant-plants, and microbial mutualists may assist in foraging for soil nutrients or fending off herbivores (Crawley 1997a). Many other influences are negative, with vertebrates and invertebrates featuring as herbivores, and microbes as pathogens (Crawley 1997a). Vertebrates, invertebrates, and

Manuscript received 14 December 2010; revised 31 May 2011; accepted 1 June 2011. Corresponding Editor: R. T. Corlett.

${ }^{3}$ Present address: School of Biological Sciences, University of Nebraska, Lincoln, Nebraska 68588 USA.

E-mail: nbeckman2@unl.edu pathogens play crucial roles in the early stages of plant recruitment, when plants experience their highest mortality. During fruit development in particular, all three groups of organisms can cause large reductions in plant fecundity (Crawley 2000) and may reduce seedling performance by damaging developing seeds (Sousa et al. 2003, Bonal et al. 2007). Particular groups of natural enemies may also interact with each other, for example, insect seed predators can damage seeds in ways that increase pathogen colonization or even act as vectors (Mills 1983). Yet the relative and absolute influences of vertebrates, invertebrates, and microbes on seed survival at the predispersal stage have rarely been investigated in forests due to the difficulty of studying processes occurring in the tree canopy (Crawley 2000, Nakagawa et al. 2005, Lewis and Gripenberg 2008).

Because invertebrates and pathogens tend to be more specialized than vertebrates in the plant species that they target, the question of the relative importance of these 
TABle 1. Study species of tropical trees and vines in central Panama and their traits.

\begin{tabular}{|c|c|c|c|c|c|c|c|c|c|c|}
\hline Species & Family & Lifeform $\dagger$ & $\begin{array}{l}\text { Dispersal } \\
\text { mode } \uparrow\end{array}$ & $\begin{array}{c}\text { Seed } \\
\text { size } \\
(\mathrm{mg}) \dagger\end{array}$ & $\begin{array}{l}\text { Fruit } \\
\text { size } \\
(\mathrm{mg})\end{array}$ & $\begin{array}{l}\text { No. } \\
\text { seed/ } \\
\text { fruit }\end{array}$ & $\begin{array}{l}\text { Physical } \\
\text { protection } \\
(\mathrm{g} / \mathrm{g}) \S\end{array}$ & $\begin{array}{l}\text { Pulp: } \\
\text { fruit } \\
(\mathrm{g} / \mathrm{g})\end{array}$ & $\begin{array}{l}\text { Capsule: } \\
\text { fruit } \\
(\mathrm{g} / \mathrm{g})\end{array}$ & $\begin{array}{c}\text { Population } \\
\text { density }\end{array}$ \\
\hline Cecropia peltata & Cecropiaceae & $\begin{array}{l}\text { midstory } \\
\text { tree }\end{array}$ & $\begin{array}{l}\text { mammal, } \\
\text { bat, bird }\end{array}$ & 0.5 & 2221.1 & 1868 & 0.54 & 0.40 & 0 & 9 \\
\hline Luehea seemannii & Tiliaceae & canopy tree & wind & 0.8 & 392.9 & 47 & 0.52 & 0 & 0.74 & $51 / 19$ \\
\hline Antirhea trichantha & Rubiaceae & canopy tree & bird & 1.5 & 34.6 & 1 & 0.85 & 0.62 & 0 & 15 \\
\hline $\begin{array}{l}\text { Stigmaphyllon } \\
\text { hypargyreum }\end{array}$ & Malpighiaceae & vine & wind & 9.8 & 34.4 & 1 & 0.60 & 0 & 0 & NA \\
\hline Bonamia trichantha & Convolvulaceae & vine & wind & 16.1 & 276.1 & 4 & 0.47 & 0 & 0.60 & NA \\
\hline Castilla elastica & Moraceae & $\begin{array}{l}\text { midstory } \\
\text { tree }\end{array}$ & $\begin{array}{l}\text { mammal, } \\
\text { bird }\end{array}$ & 203.3 & 5996.3 & 12 & 0.11 & 0.25 & 0 & 35 \\
\hline Anacardium excelsum & Anacardiaceae & $\begin{array}{l}\text { canopy } \\
\text { tree }\end{array}$ & $\underset{\text { bat }}{\operatorname{mammal}}$ & 1459.1 & 2222.9 & 1 & 0.34 & 0 & 0 & $41 / 9$ \\
\hline
\end{tabular}

Notes: Species are ordered in increasing seed size. Masses reported are dry masses. NA is not available.

$\uparrow$ S. J. Wright, personal communication.

\pm Seed reserve mass.

$\S$ Physical protection was calculated as (diaspore dry mass - seed reserve dry mass)/diaspore dry mass.

Number of individuals $\geq 1 \mathrm{~cm}$ in diameter and reproductive individuals, if known, in a 1-ha plot centered on the canopy crane.

groups in attacking plants relates to the larger unresolved question concerning the influences of specialists vs. generalists on plant communities (Maron and Crone 2006). Specialized natural enemies of plants, including many insect seed predators (Janzen 1971, Crawley 2000, Hulme and Benkman 2002) and fungal pathogens (Gallery et al. 2007, Gilbert and Webb 2007), are hypothesized to contribute particularly strongly to the maintenance of diversity through frequency-dependent mortality; generalist predators, such as vertebrate seed predators (Hammond and Brown 1998), may also contribute insofar as resistance to predation trades off with other traits (Janzen 1970, Connell 1971). Determining the influence of different natural enemy groups may direct future research in understanding whether specialists or generalists have a greater impact on plant communities and their potential role in diversity maintenance.

Fruit morphology and chemistry are likely to be particularly important in determining interspecific variation in susceptibility to seed predation and pathogen attack (Leishman et al. 2000). Observational studies of predispersal seed predation and pathogen attack suggest wide variation in attack rates among species and forest types (e.g., DeSteven 1981, Myster 1997, Forget et al. 1999, Sousa et al. 2003, Beckman and Muller-Landau 2007, Jones and Comita 2010). Morphological traits that influence seed survival include fruit size, seed size, pulpto-seed ratio, and allocation to physical protection of the diaspore. Seed size is negatively correlated with pathogen attack (Leishman et al. 2000), and positively correlated with the size of mammals consuming seeds (Dirzo et al. 2007). Seed size is also predicted to be positively correlated with insect seed predation; larger seeds, which have greater energy reserves, may be more susceptible to insect seed predators and be attacked by a greater variety of insects (large and small) than smaller seeds (Mucunguzi 1995, Espelta et al. 2009). However, larger seeds may be able to survive damage by insects better than smaller seeds (Mack 1998, Espelta et al. 2009) with potentially decreased seedling growth compared to similar-sized uninfested seeds (Sousa et al. 2003, Bonal et al. 2007). High pulp-to-seed ratios are hypothesized to have evolved to protect seeds from natural enemy attack (Mack 2000). Physical protection (i.e., mass of endocarp and testa relative to seed) increases with seed size (Moles et al. 2003) and may in part explain the greater susceptibility of small seeds to pathogen attack. Thus, the inclusion of fruit morphological data in studies ascertaining the influence of natural enemies is likely to enhance our understanding of proximate mechanisms mediating interactions between seeds and their natural enemies and provide a foundation for generalization to unstudied species.

In this study, we investigated the role of vertebrate seed predators, insect seed predators, and fungal pathogens in reducing adult fecundity of tropical canopy trees and vines, and further examined the degree to which fruit morphology explains interspecific variation in these interactions. The high diversity of tropical forests enabled us to include species that range widely in morphological traits (Table 1). We used a canopy crane to access developing fruit; to exclude each natural enemy group from these fruit; and to monitor plant responses in fruit development, seed survival, and seed qualityassessed by collecting seeds, measuring germination rates, and tracking subsequent growth. This is the first study that examines inter- and intraspecific variation in enemy-induced seed mortality in the canopy and establishes quantifiable measures using morphological fruit traits to predict the mechanism that dominates during the predispersal stage of early plant recruitment. Our manipulative canopy experiment addressed the following questions: (1) What predispersal effects do vertebrates, invertebrates, and pathogens have on seed survival and on the growth rates of surviving seedlings? (2) Does variation in fruit traits explain interspecific variation in seed survival due to vertebrate seed 
predation, insect seed predation, and/or pathogen attack?

\section{Materials and Methods}

\section{Study site and species}

The canopy crane is located in Parque Natural Metropolitano (PNM), a dry, semi-deciduous, old secondary forest located near Panama City on the Pacific coast (available online). ${ }^{4}$ The dry season in Central Panama begins in mid-December and lasts until the end of April, and the average annual rainfall at PNM is $1740 \mathrm{~mm}$. The crane reaches $42 \mathrm{~m}$ in height and covers an area of $\sim 1$ ha, providing access to 80 species of canopy plants. We selected reproductive individuals of species accessible from the crane that represent a range of life forms, dispersal modes, and families (Table 1). For all but one species, the study was conducted from January 2008 to June 2009; for Antirhea trichantha, we conducted an additional study on predispersal effects of natural enemies on germination in 2007.

\section{Experimental treatments}

Natural enemy removal treatments and controls were randomly assigned to separate branches (Appendix: Table A1). Vertebrates were excluded from fruit using lightweight exclosures designed for canopy-level work in the same forest communities (Appendix: Fig. A1; construction details in Van Bael 2003). Previous experiments showed that exclosures effectively excluded vertebrates, without affecting movement of invertebrates, and did not physically damage plants (Van Bael 2003). To remove fungal pathogens and insect seed predators, we sprayed fruits weekly with pesticides starting after pollination. Against fungal pathogens, we used Captan (N-trichloromethylthio-4-cyclohexene1, 2-dicarboximide; Arysta LifeScience North America, Cary, North Carolina, USA), a broad-spectrum fungicide that kills most seed-decay pathogens (e.g., Fusarium, Phytophthora, Pythium, and Rhizoctonia), at a concentration of $10 \mathrm{~g}$ Captan/L water, which was previously tested and used on seeds of pioneer species in Panama (Dalling et al. 1998). Against invertebrates, we used Mavrik Aquaflow (tau-fluvanilate; Wellmark International, Schaumburg, Illinois, USA) at the labelrecommended concentration of $1.48 \mathrm{~mL}$ Mavrik Aquaflow/gallon water (1 gallon is $3.8 \mathrm{~L}$ ). Mavrik Aquaflow kills a variety of invertebrates, including larvae of Diptera, Lepidoptera, Coleoptera, and Hymenoptera, with low toxicity to honey bees (Apis mellifera; Johnson et al. 2006). During the summer of 2006, we tested whether pesticide application affected vertebrate seed removal for seeds of one common tree species, Pourouma bicolor, and found no effect (data not shown).

\footnotetext{
${ }^{4}\langle$ http://striweb.si.edu/esp/〉
}

\section{Fruit development}

To determine the effects of natural enemy removal treatments on fruit development, we monitored the number of fruits that developed to maturity. We counted developing fruit biweekly until mature on marked branches within each treatment. At the beginning of the fruiting season, treatments contained $\sim 12$ 220 immature fruits depending on the species. For Bonamia trichantha, we also counted the number of healthy vs. aborted diaspores in each fruit at the end of the fruiting season. Because Cecropia peltata infructescences are long finger-like projections containing thousands of fruits and parts of the infructescence tended to be removed or aborted, we measured infructescence length instead of fruit number. We censused more frequently close to fruit maturation to determine the number of immature fruit or length of immature infructescences that successfully reached maturity and to collect mature seeds prior to removal by vertebrates.

\section{Germination}

To determine the effects of natural enemy removal treatments on seed viability, we measured germination of mature seeds collected from treatments. For Luehea seemannii, Antirhea trichantha, and Castilla elastica, we also measured diaspore mass for half of the diaspores to assess the effect of diaspore mass on germination and test for interactions with treatments. For fleshy fruits, seeds were removed from pulp in water and germinated within a week of collection (Sautu et al. 2006). Cecropia peltata seeds were processed in a dark room and airdried within two-three days of collection (Dalling et al. 1997). Due to limited growing house space, species with high longevity were stored in an air-conditioned laboratory until germination studies began (Sautu et al. 2006).

Germination trials took place in Gamboa, Panama in a growing house under $60 \%$ shade cloth and transparent plastic to protect seeds from rainfall. Different germination conditions were used to accommodate requirements of each species. Approximately 60 seeds were planted per treated branch, except for Anacardium excelsum, for which $\sim 10$ seeds were planted per branch (its low fruit production precluded larger sample sizes). Seeds of Luehea seemannii and Cecropia peltata, the smaller-seeded species, were germinated in petri dishes lined with paper towels. Large-seeded species were planted in soil collected from Barro Colorado Island mixed with sand (2 soil: 1 sand) and planted in 72 square-cavity plug sheets (LandMark Plastic, Akron, Ohio, USA). The sand-soil mixture was autoclaved for one hour at $121^{\circ} \mathrm{C}$ in a Sterilmatic steam pressure autoclave (Market Forge Industries, Everett, Massachusetts, USA). Cells of trays and petri dishes were watered individually to reduce cross-contamination of fungi. Because L. seemannii seeds have initial dormancy, seeds that did not germinate after six weeks were given a hot-water treatment; seeds were submerged in $80^{\circ} \mathrm{C}$ 
water for 2 min (Acuña and Garwood 1987, Sautu et al. 2006). In 2008, we observed some diaspores of $A$. trichantha germinating twice (once from each locule), and this was also recorded.

Germination trials ended after one month of no germination within species (Sautu et al. 2006). Seeds that did not germinate were opened to determine the status of the embryo, which was characterized as viable or dead, and with or without apparent insect or fungal damage (measured to evaluate treatment effectiveness). After germination, a subset of seedlings of Castilla elastica and Anacardium excelsum were transplanted to determine seedling relative growth rates. Complete methods and results for assessing the status of seeds that did not germinate and for measuring seedling growth rates are given in the Appendix.

\section{Morphological traits}

We measured morphological traits on 15 mature fruits collected from three individuals of each focal species (Cornelissen et al. 2003). We measured fruit length and width, the number of seeds per fruit, and the dry masses of fruit, pulp, capsule, diaspore, and seed reserve. For Anacardium excelsum, only the drupe, and not the pedicel, was considered in the following calculations. Fruit samples were dried at $60^{\circ} \mathrm{C}$ for at least $72 \mathrm{~h}$ and weighed using an analytical balance with a precision of $0.01 \mathrm{mg}$. The diaspore, or unit of dispersal, includes the seed (i.e., seed reserve and testa) and endocarp and excludes the pappus, flesh, and any other part that comes off easily. Seed reserve includes the endosperm, embryo, and cotyledons. Protective structures include the testa and all other structures of the diaspore surrounding the embryo and endosperm except for the wings or awns in wind-dispersed species (Moles et al. 2003). We calculated the following to use as morphological fruit traits: pulp-to-fruit dry mass ratios, capsuleto-fruit dry mass ratios, physical protection, $\log ($ mean fruit dry mass), $\log$ (mean fruit length), $\log$ (mean fruit width), $\log$ (mean seed reserve dry mass), and $\log$ (mean number of seeds); physical protection was calculated as (diaspore dry mass - seed reserve dry mass)/ diaspore dry mass (Moles et al. 2003). All subsequent crossspecies analyses are based on species-level means or logtransformed means.

\section{Statistical analyses}

For community-level and species-level analyses, we used a generalized linear mixed model (GLMM) with binomial errors to analyze variation in the proportion of seeds removed and germinated in response to vertebrate, invertebrate, and pathogen removal treatments. Fruits and seeds were considered experimental units. Natural enemy removal treatments were considered fixed effects. To account for spatial autocorrelation among seeds within branches and branches within trees, branches nested within trees were considered random effects, except for species-level analyses of the vine species. For these, we assumed each vine species comprised one individual, and therefore did not include individual as a random effect. To analyze variation in final fruit length of Cecropia peltata, we used a linear mixed model with normal errors and included initial length as a covariate to account for differences in initial fruit length.

In community-level analyses, we included plant responses of all species to each treatment to analyze the influence of interspecific variation in fruit morphology on fruit development, germination, and seed survival integrated over development and germination. We calculated this integrated seed survival as the proportion of fruit that developed on each branch multiplied by the proportion of seeds that germinated on each branch. Interspecific variation in fruit morphology was summarized with principal component analysis (PCA) using standardized variables of traits (i.e., correlation matrix in the PCA; Schaefer et al. 2003). In community-level analyses, natural enemy removal treatments, principal components of fruit morphology, and the interaction between treatments and principal components were included as fixed effects, and branches nested within individuals were included as random effects. An interaction between treatments and principal components indicates that responses in treatments responded differently to a particular principal component compared to controls. For example, a positive interaction between the fungicide treatment and $\mathrm{PC} 1$ in the germination analysis would indicate that germination increased at a higher rate across $\mathrm{PCl}$ in the fungicide treatment compared to the control (i.e., the slope of the fungicide treatment is steeper than the control). Cecropia peltata was not included in the community-level analysis of fruit development because fruit removal was measured in a different way than the other species. Integrated proportion of seed survival was arcsine square-root transformed to meet assumptions of normality and analyzed using a linear mixed model with normal errors with the same fixed effects as the above analyses and individual as a random effect.

For species-level analyses of germination, we included predictor variables describing interannual variation in germination and intraspecific variation in diaspore mass when data were available. For Antirhea trichantha, we had two years of germination data and included year and an interaction between year and treatment as fixed effects. To determine the effect of diaspore mass on germination within species, we included it as a covariate in species-level analyses of L. seemannii, A. trichantha, and Castilla elastica. For A. trichantha, we measured diaspore mass in 2008, and included it in analyses of germinating once or twice. We standardized diaspore mass by subtracting the mean and dividing by one standard deviation to make coefficient estimates easier to interpret (Gelman and Hill 2007). Treatments, standardized diaspore mass (SDiaM), and their interactions were included as fixed effects and branches nested within individuals as random effects in germination 
analyses. Variation of SDiaM among treatments was analyzed using a linear mixed model with normal errors.

We used the Laplace approximation of likelihoods to estimate parameters of fixed and random effects using restricted maximum likelihood estimation (Bolker et al. 2008). To analyze GLMM, we used the lme4 package in R (Bates and Maechler 2009, R Development Core Team 2009). Because of the uncertainty in calculating the degrees of freedom needed for Wald $t$ or $F$ tests, calculating $P$ values for GLMMs with normally distributed errors is controversial (Bolker et al. 2008). Instead, for normally distributed errors, we obtained 95\% confidence envelopes of parameter estimates using Markov chain Monte Carlo methods and referred to estimates as significantly different from zero if they fell outside these envelopes. When appropriate, variables were transformed to meet assumptions of normality. All statistical analyses were done using $\mathrm{R}$ ( R Development Core Team 2009).

\section{RESULTS}

\section{Fruit morphology}

There were strong correlations among many of the fruit traits (Appendix: Table A2). The first three principal components (PC1, PC2, and PC3) explained $91 \%$ of the variance (Table 2). The first principal component most strongly reflects fruit size (positively) vs. physical protection (negatively), the second reflects seed size (positively) vs. seed number per fruit (negatively), and the third reflects the capsule-to-fruit ratio (positively) vs. the pulp-to-fruit ratio (negatively).

\section{Community-level analyses}

The proportions of fruit reaching maturity and seeds germinating were significantly affected by fruit traits and their interactions with natural enemy removal treatments (Fig. 1; Appendix: Figs. A2 and A3, Tables A3A5). There was a significant positive interaction of the first principal component (i.e., fruit size vs. physical protection) with the fungicide treatment on fruit maturation $(z=2.99, P<0.01)$, germination $(z=2.34$, $P<0.05)$, and seed survival integrated over maturation and germination $(t=3.46, P<0.05)$. For the proportion of seeds surviving integrated over fruit development and germination, there was also a positive interaction between $\mathrm{PCl}$ and vertebrate exclosures $(t=2.19, P<$ $0.05)$. The probability of fruit maturation $(z=-4.82, P$ $<0.001)$, germination $(z=-1.70, P=0.0900)$, and integrated seed survival $(t=-3.33, P<0.05)$ significantly decreased with the second principal component (i.e., seed size vs. seed number per fruit). There was a marginally significant positive interaction between PC2 and the vertebrate exclosures on germination $(z=$ $1.71, P=0.0882)$. Germination $(z=2.64, P<0.01)$ and integrated seed survival $(t=2.73, P<0.05)$ significantly increased with the third principal component (i.e., capsule vs. pulp-to-fruit ratio). There was a marginally significant positive interaction between PC3 and verte-
TABLE 2. Principal component analysis of fruit morphology.

\begin{tabular}{lccc}
\hline \multicolumn{1}{c}{ Variable } & PC1 & PC2 & PC3 \\
\hline Pulp: fruit ratio & & -0.357 & $\mathbf{- 0 . 5 5 4}$ \\
Capsule: fruit ratio & & & 0.767 \\
Protective structure : diaspore ratio & $\mathbf{- 0 . 4 9 3}$ & & \\
$\log ($ fruit dry mass) & $\mathbf{0 . 4 5 3}$ & -0.210 & \\
$\log$ (fruit length) & 0.392 & -0.344 & \\
log(fruit width) & $\mathbf{0 . 4 7 7}$ & & \\
log(seed reserve dry mass) & 0.336 & $\mathbf{0 . 4 8 9}$ & -0.202 \\
$\log ($ number of seeds per fruit) & & $-\mathbf{0 . 6 7 3}$ & 0.213 \\
Cumulative percentage variance & 47.9 & 72.0 & 90.8
\end{tabular}

Notes: Only loadings greater than 0.25 are shown. Loadings greater than 0.40 are in bold.

brate exclosures on fruit development $(z=1.88, P=$ 0.0596). The main effects of PC1 and of the enemy removal treatments were not significant.

\section{Species-level analyses}

Each species was significantly affected by at least one natural enemy removal treatment during fruit development, germination, and/or the seedling stage (Appendix). The percentage of total fruit that matured and seeds that germinated varied among species from $18 \%$ to $89 \%$ and from $13 \%$ to $86 \%$, respectively (Appendix: Table A1). Insecticide significantly increased either fruit maturation or germination in four species (Figs. 2b and 3b; Appendix: Table A6). Fungicide enhanced germination in the two large-seeded species and reduced fruit maturation in two small-seeded species (Figs. 2a and 3a; Appendix: Table A6). Vertebrate exclusion increased fruit development success for three species (Fig. 2c), but had mixed effects on germination (Fig. 3c), and reduced the number of healthy diaspores per fruit in Bonamia trichantha $(z=-2.67, P<0.01$; Appendix: Table A6). The largest-seeded species in our study, Anacardium excelsum, was responsive to all natural enemy removal treatments during fruit development (fungicide, $z=2.07$, $P<0.05$; insecticide, $z=2.74, P<0.01$; vertebrate exclosure, $z=2.69, P<0.01$; Fig. 2), and all but the insecticide treatment during germination (fungicide, $z=$ 2.14, $P<0.05$; vertebrate exclosures, $z=1.822, P=$ 0.0685; Fig. 3); relative growth rates (in height and biomass) of $A$. excelsum seedlings from vertebrate exclosures were significantly higher than those of controls $(P<0.05$; Appendix: Table A6).

Within species, variation in years and diaspore mass contributed to intraspecific variation in germination and seedling growth (Appendix). For Antirhea trichantha, seed germination was significantly higher in 2008 than in 2007 ( $z=4.17, P<0.001$; Appendix: Table A6). Higher standardized diaspore mass was associated with higher germination probability for L. seemannii (SDiaM; $z=$ 4.838, $P<.001)$, lower germination probability $(z=$ $-4.14, P<0.001)$ and increased relative growth rates (in height) for $C$. elastica $(t=2.04, P<0.05)$, and had no effect in Antirhea trichantha. For $C$. elastica, reduced germination of larger seeds in controls compared to 

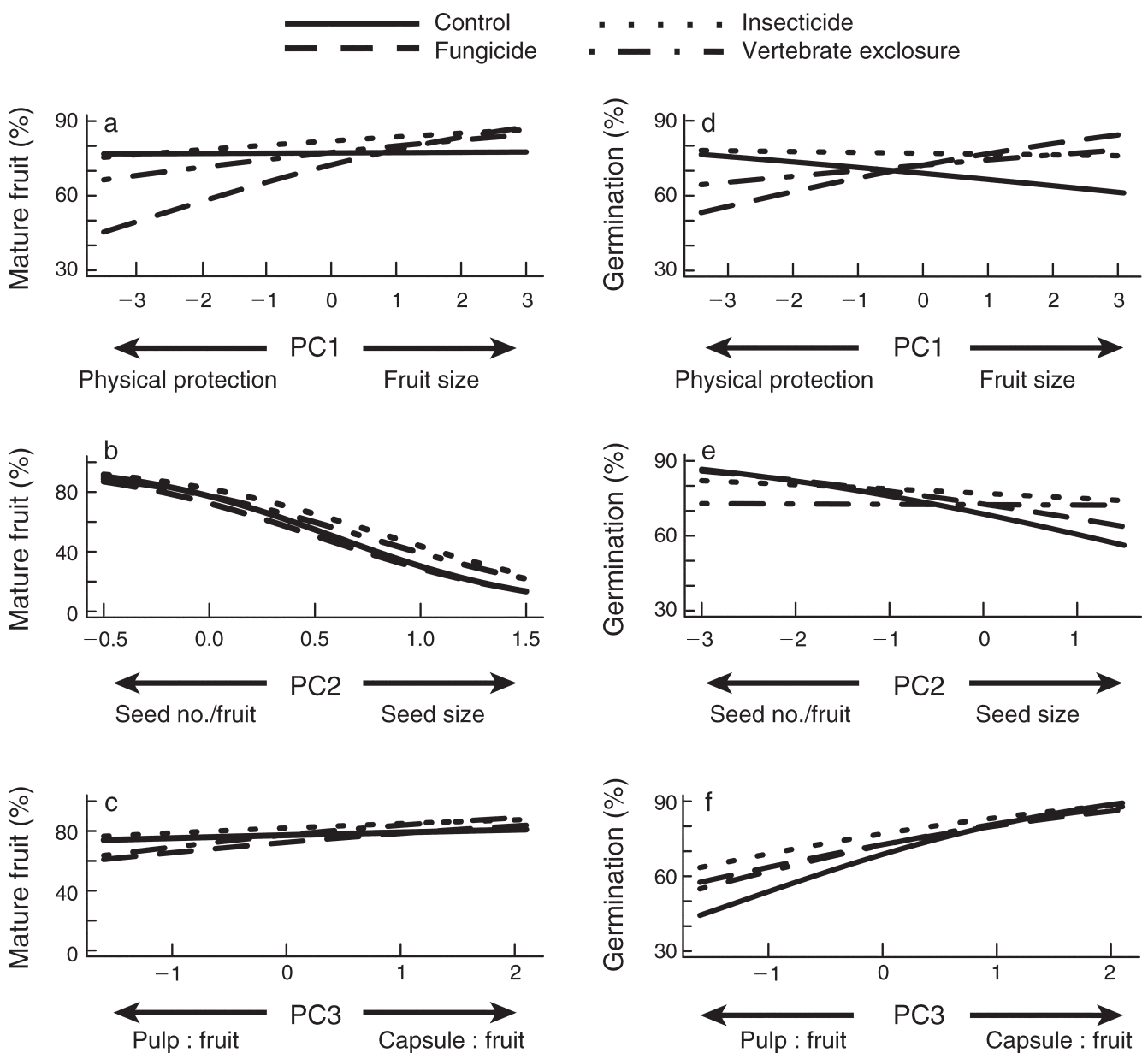

FIG. 1. The effect of natural enemy removal treatments and fruit morphology on (a-c) the probability of fruit maturation and (d-f) seed germination of tropical trees and vines in central Panama. Lines are best fits of the generalized linear mixed model using individual seeds as replicates (also see Appendix: Figs. A2 and A3). PC1, PC2, and PC3 are the first three principal components obtained from a principal component analysis of fruit morphology and explain $91 \%$ of the variance. The first principal component, $\mathrm{PC} 1$, reflects fruit size (positively) vs. physical protection (negatively), the second reflects seed size (positively) vs. seed number per fruit (negatively), and the third reflects the capsule-to-fruit ratio (positively) vs. the pulp-to-fruit ratio (negatively).

smaller seeds was most likely due to pathogenic fungi as there was a significant positive interaction between SDiaM and the fungicide treatment $(z=5.23, P<$ 0.001 ) and larger seeds had higher fungal damage in controls than smaller seeds (internal fungal damage: $z=$ $3.55, P<0.001$ ). Relative growth rates (based on height) were also slightly higher in the fungicide treatment after adjusting for diaspore mass $(t=1.74, P=0.0844)$, suggesting predispersal effects of pathogenic fungi may persist to the seedling stage.

\section{DisCUSSION}

Our results suggest that on the community level, predispersal seed predation is not due predominantly to any one group of natural enemies; instead, responses were species specific and shifted throughout the early recruitment stages studied here (i.e., fruit development, seed germination, and seedling growth). These speciesspecific responses to natural enemy removal were partly explained by interspecific variation in fruit morphology. Within species, variation in survivorship was further explained in part by diaspore size and year.

\section{Fruit traits and response to natural enemies}

We found that species with less physical protection and larger fruit experienced more pathogen attack, as PC1 predicted fruit development (Fig. 1a), germination (Fig. 1d), and integrated seed survival in the fungicide treatment. In contrast, variation among species in seed reserve mass and diaspore number per fruit (PC2) did not predict responses to the fungicide treatment. There are few studies relating pathogen susceptibility to fruit and seed morphology, and those that do focus on postdispersal stages. In one study relating seed characteristics to postdispersal seed survival, Pringle et al. (2007) found that pathogen susceptibility increased with seed size and shade tolerance and was not related to seed hardness, measured by biting seeds, which contrasts with 


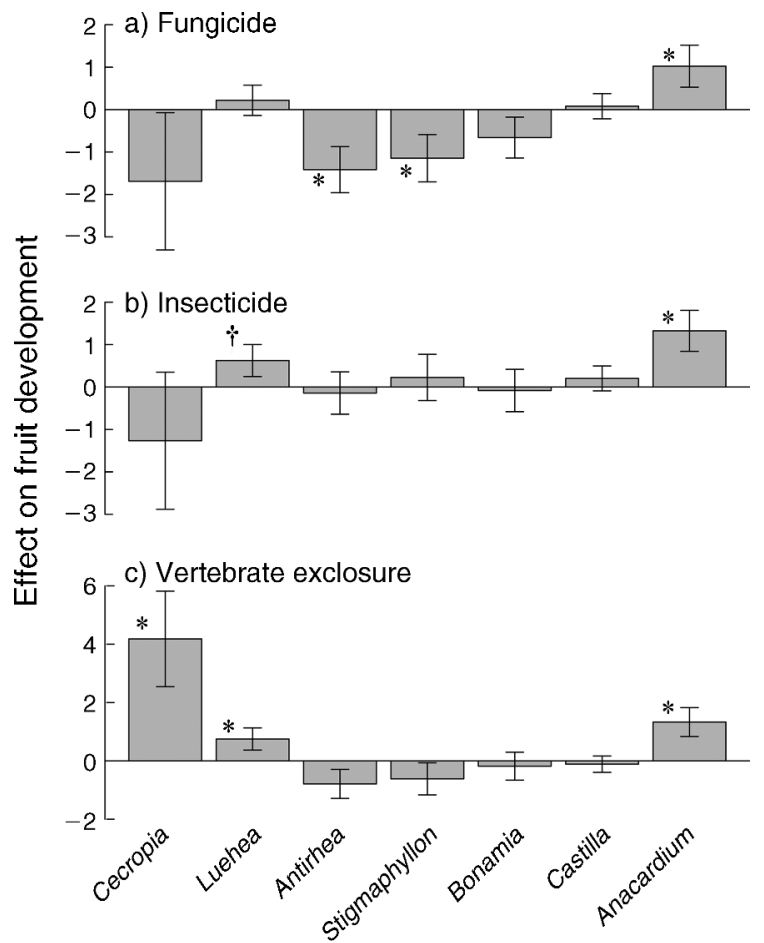

FIG. 2. Estimated effects $(+\mathrm{SE})$ of natural enemy removal treatments on fruit development (measured as log of odds ratios) in each species. Bars represent coefficient estimates of each treatment relative to control from each species-level analysis (Appendix: Table A6). Species are ordered by increasing seed mass.

$* P<0.05 ; \dagger P<0.1$.

our result on seed reserve mass. In congruence with our results, Augspurger and Kelly (1984) found that variation among wind-dispersed species in pathogeninduced seedling mortality was not explained by interspecific variation in seed mass. The negative effect of fungicide on development and germination for species with greater physical protection and smaller fruits, species negatively associated with $\mathrm{PC}$, could be due to interactions of plants with mutualistic fungi, in which seeds may be infected with endophytes that benefit seed survival (Cipollini and Stiles 1993, Gallery et al. 2007, Rodriguez et al. 2009).

Contrary to our prediction that fruit morphology explains variation in seed survival due to insect seed predation among species, we did not find this relationship. Although physical defenses surrounding seeds are predicted to reduce insect seed predation (Hulme and Benkman 2002), we did not find species with less protective structures $(\mathrm{PC} 1)$ to be more susceptible to insect seed predation. Thicker seed coats have been found to protect seeds of agricultural crops from bruchid beetles, a major insect seed predator (Theiry 1984, Kitch et al. 1991). We did not find a relationship between seed size or number per fruit (PC2) with insect seed predation in our community-level analysis. The influence of seed size on insect predation in previous studies is unclear. Larger seeds are predicted to experience higher levels of insect seed predation (Mucunguzi 1995, Espelta et al. 2009), but may be able to survive damage better than smaller seeds by satiating the predator (Mack 1998, Bonal et al. 2007, Espelta et al. 2009). In a large analysis of predispersal seed predation and seed size in Australia, Moles et al. (2003) found no relationship between seed size and survivorship. Capsules and higher pulp content may both act as physical barriers (Mack 2000, Hulme and Benkman 2002). We found no evidence of differences between species with capsules and those with high pulp content (PC3) in their protection from insect seed predators, suggesting these achieve similar effects on seed survival in response to insect seed predation among the species in our study.

Species with fleshy fruits experienced a lower probability of fruit maturation in the vertebrate exclosures compared to the controls, unlike species with capsules (PC3; Fig. 1c). Presence of vertebrates may have indirectly reduced damage of fleshy fruits by other natural enemies. Vertebrate insectivores may reduce abundances of insects near developing fruit, thereby
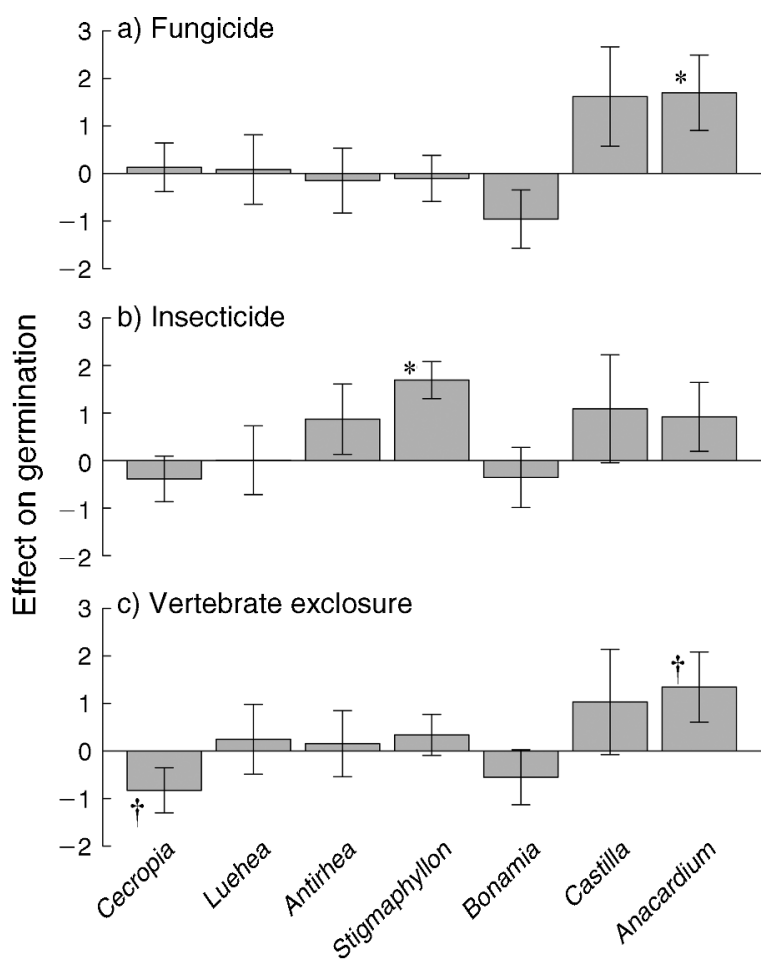

FIG. 3. Estimated effects ( $+\mathrm{SE})$ of natural enemy removal treatments on germination (measured as log of odds ratios) in each species. Bars represent coefficient estimates of each treatment relative to control from each species-level analysis (Appendix: Table A6). For Luehea seemannii, Antirhea trichantha, and Castilla elastica, coefficient estimates are adjusted by standardized diaspore mass. For A. trichantha, coefficient estimates are shown from 2008 analysis. Species are ordered in increasing seed size.

* $P<0.05 ; \dagger P<0.1$. 
reducing insect damage that may also facilitate fungal colonization or transmission (Mills 1983). Studies have documented increased herbivore abundances and foliar damage when vertebrates are excluded from leaves (Van Bael 2003, 2005, Kalka et al. 2008). Tritrophic interactions among vertebrates, fruits, and insects may have parallel consequences in reducing fruit damage and seed consumption in species with fleshy fruits.

Species with less physical protection and larger fruit (PC1) had higher seed survival integrated over fruit development and germination in vertebrate exclosures. Similarly, the vertebrate exclosures tended to increase the probability of germination for species with higher seed reserves and fewer seeds per fruit, while reducing it for species with lower seed reserves and more seeds per fruit (PC2; Fig. 1e). These results suggest that species with larger seeds and fewer seeds per fruit and species with large fruit and less physical protection suffer greater direct physical damage from vertebrates that reduce seed viability, while species with many small seeds per fruit or higher physical protection gain some benefit from being accessible to vertebrates, potentially due to tritrophic interactions with vertebrates as discussed previously. Seed predation depends on the community composition and abundance of vertebrates. Although there are few studies on the influence of interspecific variation in seed size on seed predation, defaunation tends to decrease removal at the postdispersal stage for larger seeds and increase it for smaller seeds (Beckman and Muller-Landau 2007, Dirzo et al. 2007). Although our study site, PNM, is in close proximity to Panama City, and abundances of large vertebrates have been greatly reduced due to hunting and habitat fragmentation (Ibanez et al. 2002), we found vertebrates caused the largest reductions in seed viability for species that have fewer, larger seeds per fruit.

Variation in fruit and seed morphology significantly affected fruit development and seed germination both across and within species included in our study. Species with heavier seed reserves and fewer seeds per fruit (PC2) had a lower probability of fruit maturation (Fig. 1b), germination (Fig. 1e), and integrated seed survival in the controls. Within species, seed size increased, decreased, or had no effect on germination. Our study adds to the equivocal results of other studies documenting seed survivorship at the predispersal stage, which show a range of responses including increased, decreased, or no effect of seed size on survivorship across (Moles et al. 2003, Moles and Westoby 2006) or within species (Sousa et al. 2003, Lazaro and Traveset 2009). Plant interactions with natural enemies may contribute to the opposing selective forces acting across recruitment stages that maintain variation in seed size (Janzen 1969, Espelta et al. 2009). We also found species with capsules had higher germination (Fig. 1f) and integrated seed survival compared to those with fleshy fruits (PC3). The reduced germination of species with fleshy fruits may suggest that seeds of these fruits require ingestion by vertebrates; however the hand-cleaning method we employed has been found to adequately simulate vertebrate ingestion and be sufficient for seed germination (Lobova et al. 2003, Robertson et al. 2006). Besides morphology, fruit toxicity can also mediate interactions with natural enemies (Janzen 1969). Differences in fruit toxicity among species included in this study helped explain variation in fruit development and seed survival (Beckman 2010).

\section{Effects of predispersal seed predation on plant populations and communities}

This study offers a snapshot of the influence of several groups of natural enemies on plant reproduction. Predispersal seed predation is known to vary in time and space (Crawley 2000, Kolb et al. 2007), and thus our study necessarily provides a constrained window on this phenomenon. For Antirhea trichantha, we found a significant effect of year on initial seed germination, with seeds in 2008 having a higher probability of germination than 2007. Because the insecticide treatment had a significant effect on seeds across years, but not when 2008 was analyzed separately (Fig. 3), this interannual variation in germination is potentially due to temporal variation in insect seed predation. A recent review of predispersal seed predation by insects found that interannual variation in predation was higher than spatial variation for six out of nine species (Kolb et al. 2007).

Whether the documented reductions in fecundity due to enemy attack influence population dynamics depends partly on whether plant species are more seed- or microsite-limited (Kolb et al. 2007). Seed limitation, attributed to a limited number of seeds produced and their limited dispersal, tends to be higher than microsite limitation for the majority of species that have been tested in Panama (Svenning and Wright 2005). Lower fecundity may also alter spatial distributions of recruiting seedlings by altering density-dependent processes (Janzen 1970).

Our research suggests that there is no one group of natural enemy that has a dominant effect on tropical forest plant communities at the predispersal stage. Instead, each group may differentially affect predispersal seed predation depending on interspecific variation in fruit morphology. In particular, species with larger fruit and less physical protection surrounding seeds exhibited greater negative effects of fungi on fruit development and germination, and experienced reduced seed survival integrated over fruit development and germination in response to vertebrates. Our study provides the beginnings of a mechanistic understanding of the variation in seed survival among species and highlights the importance of fruit and seed traits in mediating plant interactions with animals and microbes. Not only will incorporating plant traits benefit our basic understanding of the consequences of natural enemies for plant communities, a trait-based approach may aid 
our ability to predict changes in plant communities in the face of increasing anthropogenic pressures.

Under the myriad environmental modifications induced by humans, plant-animal interactions are expected to change with unclear outcomes for plant communities (Harvell et al. 2002, Mitchell et al. 2003, Wright et al. 2007). Identification of consistent relationships of relatively easily measured fruit traits with impacts of natural enemies on seed survival would greatly facilitate generalization to unstudied species and be useful in identifying species most at risk from anthropogenic global change. This is particularly true in tropical forest, where the high species diversity makes it logistically impossible to study every species.

\section{ACKNOWLEDGMENTS}

We thank Jim Dalling, Linda Kinkel, Claudia Neuhauser, David Tilman, Sunshine Van Bael, Marta Vargas, Sandford Weisberg, and S. J. Wright for invaluable advice. We thank Rebeca Acosta, Matt Certo, Sophia Christoforides, Amy Dickson, Reina Heinz, Bernardo Lopez, Christopher Moore, and Serica Zwack for field and laboratory assistance. The Smithsonian Tropical Research Institute provided logistical support. We are grateful for the financial support of the National Science Foundation (Graduate Research Fellowship to N. G. Beckman), the University of Minnesota Graduate School (Doctoral Dissertation Fellowship and International Research Grant to N. G. Beckman), the University of Minnesota Department of Ecology, Evolution and Behavior (Block Grant to N. G. Beckman), the Smithsonian Tropical Research Institute (Supplementary Award to N. G. Beckman), the Bell Museum of Natural History (Dayton Natural History Fund to N. G. Beckman), and the HSBC Climate Partnership (H. C. Muller-Landau).

\section{Literature Cited}

Acuña, P., and N. Garwood. 1987. Efecto de la luz y la escarificación en las semillas de cinco especies de árboles secundarios. Revista de Biologia Tropical 35:203-207.

Augspurger, C., and C. Kelly. 1984. Pathogen mortality of tropical tree seedlings: experimental studies of the effects of dispersal distance, seedling density, and light conditions. Oecologia 61:211-217.

Bates, D., and M. Maechler. 2009. lme4: linear mixed-effects models using S4 classes. 〈http://CRAN.R-project.org/ package $=$ Ime 4$\rangle$

Beckman, N. G. 2010. Effects of vertebrates, insects, and pathogens on patterns of early plant recruitment in tropical forests. Dissertation. University of Minnesota, Saint Paul, Minnesota, USA.

Beckman, N. G., and H. C. Muller-Landau. 2007. Differential effects of hunting on pre-dispersal seed predation and primary and secondary seed removal of two neotropical tree species. Biotropica 39:328-339.

Bolker, B. M., M. Brooks, C. Clark, S. Geange, J. Poulsen, M. Stevens, and J. White. 2008. Generalized linear mixed models: a practical guide for ecology and evolution. Trends in Ecology and Evolution 23:127-135.

Bonal, R., A. Munoz, and M. Diaz. 2007. Satiation of predispersal seed predators: the importance of considering both plant and seed levels. Evolutionary Ecology 21:367-380.

Cipollini, M. L., and E. W. Stiles. 1993. Fungi as biotic defense of fleshy fruits: alternative hypotheses, predictions, and evidence. American Naturalist 141:663-673.

Coley, P. D., and J. A. Barone. 1996. Herbivory and plant defenses in tropical forests. Annual Review of Ecology and Systematics 27:305-335.
Connell, J. H. 1971. On the role of natural enemies in preventing competitive exclusion in some marine animals and in rain forests. Pages 298-312 in P. J. Den Boer and G. R. Gradwell, editors. Dynamics of populations. Center for Agricultural Publishing and Documentation, Wageningen, The Netherlands.

Cornelissen, J. H. C., S. Lavorel, E. Garnier, S. Diaz, N. Buchmann, D. E. Gurvich, P. B. Reich, H. ter Steege, H. D. Morgan, M. G. A. van der Heijden, J. G. Pausas, and H. Poorter. 2003. A handbook of protocols for standardised and easy measurement of plant functional traits worldwide. Australian Journal of Botany 51:335-380.

Crawley, M. J., editor. 1997a. Plant ecology. Blackwell Scientific, Cambridge, Massachusetts, USA.

Crawley, M. J. 1997b. Plant-herbivore dynamics. Pages 401474 in M. J. Crawley, editor. Plant ecology. Blackwell Scientific, Cambridge, Massachusetts, USA.

Crawley, M. J. 2000. Seed predators and plant population dynamics. Pages 167-182 in M. Fenner, editor. Seeds: the ecology of regeneration in plant communities. CAB International, Wallingford, UK.

Dalling, J. W., M. Swaine, and N. Garwood. 1997. Soil seed bank community dynamics in seasonally moist lowland tropical forest, Panama. Journal of Tropical Ecology 13:659-680.

Dalling, J. W., M. D. Swaine, and N. C. Garwood. 1998. Dispersal patterns and seed bank dynamics of pioneer trees in moist tropical forest. Ecology 79:564-578.

DeSteven, D. 1981. Pre-dispersal seed predation in a tropical shrub (Mabea occidentalis, Euphorbiaceae). Biotropica 13:146-150.

Dirzo, R., E. Mendoza, and P. Ortiz. 2007. Size-related differential seed predation in a heavily defaunated Neotropical rain forest. Biotropica 39:355-362.

Espelta, J. M., R. Bonal, and B. Sanchez-Humanes. 2009. Predispersal acorn predation in mixed oak forests: interspecific differences are driven by the interplay among seed phenology, seed size and predator size. Journal of Ecology 97:14161423.

Forget, P. M., K. Kitajima, and R. B. Foster. 1999. Pre- and post-dispersal seed predation in Tachigali versicolor (Caesalpiniaceae): effects of timing of fruiting and variation among trees. Journal of Tropical Ecology 15:61-81.

Gallery, R. E., J. W. Dalling, and A. E. Arnold. 2007. Diversity, host affinity, and distribution of seed-infecting fungi: a case study with Cecropia. Ecology 88:582-588.

Gelman, A., and J. Hill. 2007. Data analysis using regression and multilevel/hierarchical models. Cambridge University Press, New York, New York, USA.

Gilbert, G. 2002. Evolutionary ecology of plant diseases in natural ecosystems. Annual Review of Phytopathology 40:13-43.

Gilbert, G., and C. O. Webb. 2007. Phylogenetic signal in plant pathogen-host range. Proceedings of the National Academy of Sciences USA 104:4979-4983.

Hammond, D. S., and V. K. Brown. 1998. Disturbance, phenology and life-history characteristics: factors influencing distance/density-dependent attack on tropical seeds and seedlings. Pages 51-78 in D. M. Newbery, H. H. T. Prins, and N. D. Brown, editors. Dynamics of tropical communities. Blackwell, Oxford, UK.

Harvell, C. D., C. E. Mitchell, J. R. Ward, S. Altizer, A. P. Dobson, R. S. Otsfeld, and M. D. Samuel. 2002. Climate warming and disease risks for terrestrial and marine biota. Science 296:2158-2162.

Hulme, P., and C. Benkman. 2002. Granivory. Pages 132-154 in $\mathrm{C}$. Herrera and O. Pellmyr, editors. Plant-animal interactions: an evolutionary approach. Blackwell Publishing, Oxford, UK.

Ibanez, R., R. Condit, G. Angehr, S. Aguilar, T. Garcia, R. Martinez, A. Sanjur, R. Stallard, S. J. Wright, A. S. Rand, 
and S. Heckadon. 2002. An ecosystem report on the Panama Canal: monitoring the status of the forest communities and the watershed. Environmental Monitoring and Assessment 80:65-95.

Janzen, D. 1969. Seed-eaters versus seed size, number, toxicity and dispersal. Evolution 23:1-27.

Janzen, D. H. 1970. Herbivores and the number of tree species in tropical forests. American Naturalist 104:501-527.

Janzen, D. H. 1971. Seed predation by animals. Annual Review of Ecology and Systematics 1:119-123.

Johnson, R. M., Z. M. Wen, M. A. Schuler, and M. R. Berenbaum. 2006. Mediation of pyrethroid insecticide toxicity to honey bees (Hymenoptera: Apidae) by cytochrome P450 monooxygenases. Journal of Economic Entomology 99:1046-1050.

Jones, F. A., and L. Comita. 2010. Density-dependent predispersal seed predation and fruit set in a tropical tree. Oikos 119:1841-1847.

Kalka, M. B., A. R. Smith, and E. K. Kalko. 2008. Bats limit arthropods and herbivory in a tropical forest. Science 320:71.

Kitch, L., R. Shade, and L. Murdock. 1991. Resistance to the cowpea weevil (Callosobruchus maculatus) larva in pods of cowpea (Vigna unguiculata). Entomologia Experimentalis et Applicata 60:183-192.

Kolb, A., J. Ehrlen, and O. Eriksson. 2007. Ecological and evolutionary consequences of spatial and temporal variation in pre-dispersal seed predation. Perspectives in Plant Ecology, Evolution and Systematics 9:79-100.

Lazaro, A., and A. Traveset. 2009. Does the spatial variation in selective pressures explain among-site differences in seed mass? A test with Buxus balearica. Evolutionary Ecology 23:847-865.

Leishman, M. R., I. J. Wright, A. T. Moles, and M. Westoby. 2000. The evolutionary ecology of seed size. Pages 31-57 in M. Fenner, editor. Seeds: the ecology of regeneration in plant communities. CAB International, Wallingford, UK.

Lewis, O. T., and S. Gripenberg. 2008. Insect seed predators and environmental change. Journal of Applied Ecology 45:1593-1599.

Lobova, T. A., S. A. Mori, F. Blanchard, H. Peckham, and P. Charles-Dominique. 2003. Cecropia as a food resource for bats in French Guiana and the significance of fruit structure in seed dispersal and longevity. American Journal of Botany 90:388-403.

Mack, A. 1998. An advantage of large seed size: tolerating rather than succumbing to seed predators. Biotropica 30:604-608.

Mack, A. 2000. Did fleshy fruit pulp evolve as a defense against seed loss rather than as a dispersal mechanism. Journal of Bioscience 25:93-97.

Maron, J. L., and E. Crone. 2006. Herbivory: effects on plant abundance, distribution and population growth. Proceedings of the Royal Society B 273:2575-2584.

Mills, J. 1983. Insect-fungus associations influencing seed deterioration. Phytopathology 73:330-335.

Mitchell, C. E., P. B. Reich, D. Tilman, and J. V. Groth. 2003. Effects of elevated $\mathrm{CO} 2$, nitrogen deposition, and decreased species diversity on foliar fungal plant disease. Global Change Biology 9:438-451.

Moles, A. T., D. I. Warton, and M. Westoby. 2003. Do smallseeded species have higher survival through seed predation than large-seed species? Ecology 84:3148-3161.

Moles, A. T., and M. Westoby. 2006. Seed size and plant strategy across the whole life cycle. Oikos 113:91-105.

Mucunguzi, P. 1995. Bruchids and survival of Acacia seeds. African Journal of Ecology 33:175-183.

Myster, R. W. 1997. Seed predation, disease and germination on landslides in Neotropical lower montane wet forest. Journal of Vegetation Science 8:55-64.

Nakagawa, M., Y. Takeuchi, K. Tanaka, and N. Tohru. 2005. Predispersal seed predation by insects vs. vertebrates in six dipterocarp species in Sarawak, Malaysia. Biotropica 37:389 396.

Pringle, E. G., P. Álvarez-Loayza, and J. Terborgh. 2007. Seed characteristics and susceptibility to pathogen attack in tree seeds of the Peruvian Amazon. Plant Ecology 193:211-222.

R Development Core Team. 2009. R: a language and environment for statistical computing. R Foundation for Statistical Computing, Vienna, Austria.

Robertson, A., A. Trass, J. Ladley, and D. Kelly. 2006. Assessing the benefits of frugivory for seed germination: the importance of the deinhibition effect. Functional Ecology 20:58-66.

Rodriguez, R. J., J. F. White, A. E. Arnold, and R. S. Redman. 2009. Fungal endophytes: diversity and functional roles. New Phytologist 182:314-330.

Sautu, A., J. M. Baskin, C. C. Baskin, and R. Condit. 2006. Studies on the seed biology of 100 native species of trees in a seasonal moist tropical forest, Panama, Central America. Forest Ecology and Management 234:245-263.

Schaefer, H., V. Schmidt, and H. Winkler. 2003. Testing the defence trade-off hypothesis: how contents of nutrients and secondary compounds affect fruit removal. Oikos 102:318328 .

Sousa, W. P., P. G. Kennedy, and B. J. Mitchell. 2003. Propagule size and predispersal damage by insects affect establishment and early growth of mangrove seedlings. Oecologia 135:564-575.

Svenning, J. C., and S. J. Wright. 2005. Seed limitation in a Panamanian forest. Journal of Ecology 93:853-862.

Theiry, D. 1984. Hardness of some Fabaceous seed coats in relation to larval penetration by Acanthoscelides obtectus (Say) (Coleoptera: Bruchidae). Journal of Stored Products Research 20:177-181.

Van Bael, S. A. 2003. The direct and indirect effects of insectivory by birds in two neotropical forests. University of Illinois, Urbana-Champaign, Illinois, USA.

Van Bael, S. A. 2005. The direct and indirect effects of insectivory by birds in two contrasting Neotropical forests. Oecologia 143:106-116.

Wright, S. J., K. E. Stoner, N. G. Beckman, R. T. Corlett, R. Dirzo, H. C. Muller-Landau, G. Nuñez-Iturri, C. A. Peres, and B. C. Wang. 2007. The plight of animals in tropical forests and the consequences for plant regeneration. Biotropica 39:289-291.

\section{APPENDIX}

Supplemental materials and methods for assessing seed viability following germination trials and measuring seedling growth rates as well as supplemental results for community- and species-level analyses (Ecological Archives E092-185-A1). 